\title{
Keseimbangan asam-basa tubuh dan kejadian sindrom metabolik pada remaja obesitas
}

Acid-base balance and metabolic syndrome among obese adolescent

\section{Firdananda Fikri Jauharany, Nurmasari Widyastuti}

Program Studi S1 Ilmu Gizi, Fakultas Kedokteran Universitas Diponegoro

\begin{abstract}
Background: The prevalence of metabolic syndrome increased in young population, indicated by the rise in obesity among children and adolescent. Western dietary pattern was one of the causes. Western diet rich in animal protein can produce acid during metabolic process and may cause an acid-excess in the body (dietary acid load). This process was contributed to acid-base balance through the metabolism of sulfur-containing amino acids (cysteine and methionine) which produce $H^{+}$ions as well as lowering the pH. Objective: To examine the association between acid-base balance and components of metabolic syndrome among obese adolescent. Method: A cross-sectional study was conducted on 40 obese adolescent in Semarang high school. We measured Potential Renal Acid Load (PRAL) score and $\mathrm{pH}$ urine as acid-base indicator. MetS is defined $\geq 3$ following risk factors: waist circumference $\geq 90$ th percentile, blood pressure $\geq 90$ th percentile, triglycerides $\geq 110 \mathrm{mg} / \mathrm{dl}$, HDL levels $\leq 40 \mathrm{mg} / \mathrm{dl}$, and fasting blood glucose levels $\geq 110 \mathrm{mg} / \mathrm{dl}$. Normality test used the Shapiro-Wilk test $(n<50)$. Bivariate analysis used Pearson test, Rank-Spearman test, and Chi-Square test. Results: PRAL score was associated with waist circumference $(r=0,347 ; p=0,028)$, sistolic blood pressure $(r=0,590 ; p=<0,001)$, diastolic blood pressure $(r=0,668 ; p=<0,001)$, and triglyceride levels $(r=0,362 ; p=0,022)$. pH urin was not associated with any risk factors of MetS. Conclusion: High dietary acid load may be a risk factor for the development of MetS.
\end{abstract}

KEYWORDS: adolescent; blood pressure; dietary acid load; obesity; PRAL score; trygliceride; waist circumference

\begin{abstract}
ABSTRAK
Latar belakang: Prevalensi sindrom metabolik (SM) meningkat pada populasi muda seiring meningkatnya obesitas dikalangan anak-anak dan remaja. Pola makan kebarat-baratan merupakan salah satu penyebabnya. Diet Western yang kaya produk makanan hewani dapat menghasilkan asam saat proses metabolisme sehingga dapat menyebabkan berlebihnya asam dalam tubuh yang disebut dietary acid load, yang berkontribusi terhadap keseimbangan asam-basa melalui metabolisme sulfur yang mengandung asam amino sistein dan metionin dengan menghasilkan ion $\mathrm{H}^{+}$dan menurunkan $\mathrm{pH}$. Tujuan: Mengetahui hubungan keseimbangan asam-basa tubuh dengan komponen-komponen sindrom metabolik. Metode: Penelitian cross-sectional dilakukan pada 40 remaja di Kota Semarang. Skor potential renal acid load (sPRAL) dan $\mathrm{pH}$ urin merupakan indikator keseimbangan asam-basa. SM didefinisikan apabila subjek memiliki $\geq 3$ komponen yaitu persentil lingkar pinggang (LP) $\geq 90$; persentil tekanan darah (TD) $\geq 90$; trigliserida $\geq 110 \mathrm{mg} / \mathrm{dl}$; high density lipoprotein $(\mathrm{HDL}) \leq 40 \mathrm{mg} / \mathrm{dl}$; dan glukosa darah puasa (GDP) $\geq 110 \mathrm{mg} / \mathrm{dl}$. Uji normalitas menggunakan uji Shapiro-Wilk $(\mathrm{n}<50)$. Analisis bivariat menggunakan uji Pearson, Rank Spearman dan Chi-Square. Hasil: Ada hubungan yang signifikan antara skor PRAL dengan LP $(\mathrm{r}=0,347$; $\mathrm{p}=0,028)$; tekanan darah sistolik $(\mathrm{r}=0,590 ; \mathrm{p}=<0,001)$; tekanan darah diastolik $(\mathrm{r}=0,668 ; \mathrm{p}=<0,001)$; dan kadar trigliserida $(\mathrm{r}=0,362 ; \mathrm{p}=0,022)$. Tidak ada hubungan antara $\mathrm{pH}$ urin dengan semua komponen sindrom metabolik. Simpulan: Tingginya dietary acid load merupakan salah satu faktor risiko terjadinya sindrom metabolik
\end{abstract}

KATA KUNCI: remaja; tekanan darah; dietary acid load; obesitas; PRAL; trigliserida; lingkar pinggang

\section{PENDAHULUAN}

Prevalensi obesitas meningkat di setiap negara, pada setiap jenis kelamin dan pada semua kelompok usia, termasuk kelompok usia remaja (1). Menurut laporan "International Obesity Task Force" (IOTF) setidaknya
45 juta anak-anak usia 5 sampai 17 tahun dinyatakan obesitas (2). Obesitas menyebabkan peningkatan risiko

Korespondensi: Firdananda Fikri Jauharany, Program Studi S1 Ilmu Gizi, Fakultas Kedokteran Universitas Diponegoro, Jl. Prof. Soedarto, S.H. Tembalang, Kota Semarang, Jawa Tengah, Indonesia, e-mail: firdananda22@gmail.com 
munculnya sindrom metabolik. Sindrom metabolik merupakan kumpulan kelainan metabolik komplek yang muncul sebagai faktor risiko penyakit kardiovaskular serta diabetes mellitus tipe 2. Berdasarkan penelitian yang dilakukan sebelumnya diketahui prevalensi remaja obesitas usia 15-18 tahun di Kota Semarang yang mengalami sindrom metabolik sebanyak 15,2\% (3). Faktor gaya hidup, terutama aktivitas fisik dan asupan, dianggap sebagai faktor utama yang berkontribusi terhadap kejadian sindrom metabolik. Pola makan remaja yang cenderung kebarat-baratan dalam jangka panjang dapat menyebabkan asidosis metabolik ringan, telah diidentifikasi sebagai faktor risiko untuk pengembangan obesitas, gangguan lipid, diabetes, dan hipertensi.

Sindrom metabolik berhubungan dengan berbagai perubahan fisiologis dan metabolisme. Perubahan dalam mekanisme homeostatis ginjal juga telah dikaitkan dengan sindrom metabolik dan komponen-komponennya (4). Retensi natrium dan asam urat terkait dengan resistensi insulin (5) sedangkan keadaan hiperhemodinamik ginjal juga dipengaruhi dari keadaan obesitas (6). Salah satu manifestasi ginjal terhadap sindrom metabolik adalah urin yang terlalu asam. Sebuah penelitian menemukan bahwa subjek dengan sindrom metabolik memiliki $\mathrm{pH}$ urine yang lebih rendah dibandingkan dengan subjek tanpa sindrom metabolik (7).

Keseimbangan asam-basa dikendalikan secara seksama karena perubahan $\mathrm{pH}$ dapat memberikan pengaruh terhadap beberapa organ tubuh. Keseimbangan asam-basa terkait dengan pengaturan konsentrasi ion hidrogen bebas dalam cairan tubuh. Konsentrasi ion hidrogen sangat mempengaruhi proses metabolisme yang berlangsung dalam tubuh karena hampir semua aktivitas enzim dipengaruhi oleh konsentrasi ion hidrogen. Menurunnya $\mathrm{pH}$ urin menunjukkan bahwa tubuh mengalami keadaan asidosis metabolik yaitu gangguan keseimbangan asam-basa yang ditandai dengan penurunan $\mathrm{pH}$ darah sebagai akibat rendahnya kadar bikarbonat dalam darah atau peningkatan konsentrasi ion hidrogen (8).

Asupan berkontribusi terhadap keseimbangan asambasa melalui metabolisme sulfur yang mengandung asam amino sistein dan metionin dengan menghasilkan ion $\mathrm{H}^{+}$dan menurunkan $\mathrm{pH}$ (9). Asupan yang berkontribusi terhadap acid load adalah sulfat (hasil dari metabolisme protein) dan fosfor sedangkan asupan yang bermuatan basa biasanya berkaitan dengan kation mineral kalium, magnesium, dan kalsium (10). Daging, ikan, keju, serealia, tepung, dan beras merupakan makanan yang relatif kuat dalam mengasamkan tubuh sedangkan buah, legume, sayuran, anggur merah, dan kentang merupakan makanan yang relatif kuat sifat basanya dalam tubuh (11). Diet Western yang kaya produk makanan hewani dan menghasilkan asam saat proses metabolisme dapat menyebabkan berlebihnya asam dalam tubuh atau disebut dietary acid load. Dietary acid load yang tidak diimbangi dengan konsumsi buah dan sayur dalam jangka waktu lama, dapat menyebabkan metabolisme asidosis ringan hingga kronis (12). Dietary acid load dapat dihitung menggunakan formula potential renal acid load (PRAL). Selain itu, pH urin juga digunakan sebagai indikator status asam-basa tubuh karena mudah, tidak invasif, dan murah. $\mathrm{pH}$ urin dapat secara cepat berubah dalam merespon asupan seseorang (13).

Beberapa penelitian telah menunjukkan bahwa dietary acid load berkaitan dengan peningkatan kejadian hipertensi dan diabetes mellitus tipe 2. Penelitian sebelumnya di Jepang pada 1.136 mahasiswa kesehatan menunjukkan peningkatan risiko hipertensi terjadi sebesar $23 \%$ pada subjek dengan skor PRAL yang tinggi (14). Selain itu, hasil penelitian sebelumnya pada tahun 2014 menunjukkan subjek dengan skor PRAL tinggi mencerminkan potensi pembentukan asam dalam tubuh yang lebih besar dan berkaitan dengan peningkatan yang signifikan terhadap risiko diabetes mellitus tipe 2 (15). Penelitian lainnya juga telah membuktikan bahwa dietary acid load berkaitan dengan $\mathrm{pH}$ urin. Berdasarkan penelitian di Inggris menunjukkan bahwa semakin rendah skor PRAL menunjukkan $\mathrm{pH}$ urin yang semakin basa (9). Penelitian mengenai asupan yang mempengaruhi keseimbangan asam-basa (dietary acid load) di Indonesia masih terbilang jarang. Berdasarkan latar belakang tersebut, peneliti ingin menganalisis hubungan keseimbangan asam-basa tubuh dengan kejadian sindrom metabolik pada remaja obesitas.

\section{BAHAN DAN METODE}

Penelitian ini merupakan penelitian deskriptif analitik dengan menggunakan pendekatan cross-sectional 
yang dilaksanakan di SMA Negeri 1 Semarang dan SMA Negeri 12 Semarang. Pengambilan data dilakukan pada bulan Agustus hingga September 2016. Populasi target penelitian ini adalah seluruh remaja obesitas di Kota Semarang. Populasi terjangkau dalam penelitian ini yaitu siswa obesitas di SMA Negeri 1 Semarang dan SMA Negeri 12 Semarang. Pemilihan sampel dilakukan dengan metode consecutive sampling. Besar sampel dihitung menggunakan rumus estimasi proporsi untuk suatu populasi. Proporsi remaja yang mengalami sindrom metabolik berdasarkan penelitian sebelumnya sebesar $15,2 \%(0,152)$ dengan nilai $\mathrm{Z} \alpha=1,64 ; \mathrm{Q}=0,848$; dan nilai presisi (d) sebesar 0,01 sehingga diperoleh jumlah sampel sebanyak 36 subjek dan untuk menghindari drop out ditambahkan 10\% sehingga jumlah sampel menjadi 40 subjek.

Kriteria inklusi subjek adalah bersedia menjadi sampel penelitian dengan mengisi informed consent, mengalami obesitas yang ditandai dengan indeks massa tubuh berdasarkan umur (IMT/U) persentil $>95$, maupun obesitas sentral yang ditandai dengan lingkar pinggang $\geq$ persentil ke-90 ( $\geq 93 \mathrm{~cm}$ untuk laki-laki dan $\geq 87 \mathrm{~cm}$ untuk perempuan), tidak sedang mengkonsumsi obat-obatan (parasetamol, metformin, nukleosida, lithium, cylosporine, obat-obatan antihipertensi, NSAIDs, dan obat-obatan diuretik) dan multivitamin, tidak sedang menjalankan diet tertentu, tidak sedang mengalami infeksi saluran kemih (ISK), tidak merokok, dan tidak memiliki penyakit diabetes melitus. Kriteria eksklusi dalam penelitian ini adalah subjek tidak hadir selama pengambilan data berlangsung dan mengundurkan diri sebelum penelitian selesai.

Variabel bebas dalam penelitian ini adalah keseimbangan asam-basa yang diukur menggunakan skor PRAL (dietary acid load) dan pH urin. Skor PRAL dihitung setelah mengetahui asupan harian responden, yang kemudian dimasukkan ke dalam rumus berikut: PRAL $(\mathrm{mEq} /$ hari $)=0,4888 \times$ asupan protein $(\mathrm{g} /$ hari $)$ $+0,0366 \times$ asupan fosfor (mg/hari) $-0,0205 \times$ asupan kalium (mg/hari) - 0,0125 x kalsium (mg/hari) - 0.0263 $\times$ magnesium (mg/hari) (12). Sampai saat ini belum ada standar baku dalam pengkategorian skor PRAL sehingga mengacu pada penelitian-penelitian sebelumnya, mean (rata-rata) dari data dalam penelitian ini digunakan untuk mengkategorikan skor PRAL.
Data asupan diperoleh melalui wawancara kebiasaan konsumsi makanan menggunakan formulir food recall selama 3 hari. Data asupan yang digunakan dalam satuan gram (g) dan dianalisis menggunakan software nutrisurvey. Pengambilan sampel urin juga dilakukan untuk pemeriksaan $\mathrm{pH}$ urin. Sampel urin yang dikumpulkan dalam penelitian ini adalah urin pertama saat bangun tidur di pagi hari. Urin ini lebih pekat dari urin yang dikeluarkan pada siang hari sehingga sangat baik sekali untuk pemeriksaan urin rutin.

Variabel terikat dalam penelitian ini adalah kejadian sindrom metabolik. Penentuan sindrom metabolik ditentukan berdasarkan kriteria dari National Cholesterol Education Program Adult Treatment Panel III (NCEP ATP III) yaitu seseorang dikatakan mengalami sindrom metabolik bila memiliki sedikitnya 3 dari 5 kriteria sebagai berikut yaitu mengalami obesitas sentral (lingkar perut $\geq$ persentil ke-90, yaitu $\geq 93 \mathrm{~cm}$ untuk laki-laki dan $\geq 87 \mathrm{~cm}$ untuk perempuan) (16); hipertensi (tekanan darah $\geq$ persentil ke-95, yaitu $>130 / 90$ mmHg yaitu untuk laki-laki dan $>120 / 80$ mmHg untuk perempuan (17); kadar trigliserida $\geq 110 \mathrm{mg} / \mathrm{dl}$; kadar kolesterol high density lipoprotein (HDL) $\leq 40 \mathrm{mg} / \mathrm{dl}$; dan kadar glukosa darah puasa $\geq 110 \mathrm{mg} / \mathrm{dl}$. Pada penelitian ini, dilakukan pengukuran antropometri, tekanan darah, dan pemeriksaan sampel darah. Pengukuran antropometri yang dilakukan meliputi pengukuran berat badan (BB) menggunakan timbangan injak digital dengan ketelitian $0,1 \mathrm{~kg}$ dan pengukuran tinggi badan (TB) menggunakan microtoise dengan ketelitian 0,1 cm. Data BB dan TB digunakan untuk menentukan status gizi berdasarkan persentil IMT/U. Pengukuran lingkar pinggang (LP) menggunakan metline dengan ketelitian 0,1 cm. Data tekanan darah subjek diukur langsung dengan menggunakan sphygmomanometer air raksa oleh tenaga ahli kesehatan. Pemeriksaan tekanan darah dilakukan setelah pasien duduk tenang selama 5 menit tidak bergerak maupun berbicara, kaki menempel di lantai dan posisi lengan disangga setinggi jantung. Tekanan darah diambil 2 kali pada lengan kanan dengan selang waktu 2 menit dan diambil rerata hasil keduanya.

Pemeriksaan sampel darah dilakukan pada subjek yang telah berpuasa selama 8-12 jam, meliputi pemeriksaan kadar kolestrol HDL, kadar trigliserida, dan kadar GDP menggunakan teknik kimiawi kolorimetrik 
dan metode enzymatic colorimetric di Laboratorium Sarana Medika Semarang. Selain itu, dilakukan juga wawancara mengenai aktivitas fisik menggunakan International Physical Activity Questionnaire (IPAQ).

Analisis univariat digunakan untuk mendeskripsikan karakteristik sampel berupa usia, jenis kelamin, LP, skor PRAL, pH urin, tekanan darah, kadar GDP, trigliserida, HDL, aktivitas fisik, serta asupan makan. Uji normalitas data menggunakan uji Saphiro-Wilk $(\mathrm{n}<50)$ dengan nilai $p>0,05$. Analisis bivariat digunakan untuk mengetahui hubungan keseimbangan asam-basa dengan komponen sindrom metabolik menggunakan uji korelasi Pearson jika data berdistribusi normal dan Rank Spearman jika data berdistribusi tidak normal. Uji korelasi ChiSquare juga dilakukan untuk mengetahui hubungan keseimbangan asam-basa yang diukur menggunakan skor PRAL dan $\mathrm{pH}$ urin dengan kejadian sindrom metabolik. Analisis data menggunakan program komputer dengan tingkat kemaknaan $\alpha=0,05$.

\section{HASIL}

\section{Karakteristik subjek penelitian}

Skrining awal melibatkan 1.360 subjek yang berasal dari SMA Negeri 1 Semarang dan SMA Negeri 12 Semarang dengan melakukan pengukuran berat badan, tinggi badan, dan lingkar pinggang. Hasil skrining menunjukkan sebanyak 124 siswa mengalami obesitas. Dari 124 siswa yang mengalami obesitas, 40 diantaranya menjadi subjek penelitian. Subjek penelitian berjumlah 40 orang dengan rentang usia 14-17 tahun. Rentang skor aktivitas fisik subjek pada penelitian ini adalah 240-594 MET-menit/minggu. Hasil perhitungan skor aktivitas fisik menunjukkan bahwa semua subjek memiliki aktivitas fisik dalam kategori ringan. Hasil pengukuran $\mathrm{pH}$ urin dalam penelitian ini berkisar antara 5,0-7,0, yang menunjukkan bahwa $\mathrm{pH}$ urin semua subjek masih tergolong normal. Sebanyak 16 subjek (40\%) mengalami sindrom metabolik dan 24 subjek $(60 \%)$ tidak mengalami sindrom metabolik. Tabel 1 menunjukkan bahwa sindrom metabolik lebih banyak dijumpai pada remaja laki-laki $(32,5 \%)$ daripada remaja perempuan $(7,5 \%)$.

Tabel 2 menampilkann asupan zat gizi yang berpengaruh terhadap keseimbangan asam basa tubuh.
Tabel 1. Karakteristik subjek

\begin{tabular}{|c|c|c|}
\hline Variabel & $\mathbf{n}$ & $\%$ \\
\hline \multicolumn{3}{|l|}{ Jenis kelamin } \\
\hline Laki-laki & 24 & 60 \\
\hline Perempuan & 16 & 40 \\
\hline \multicolumn{3}{|l|}{ Aktivtas fisik } \\
\hline Ringan & 40 & 100 \\
\hline Sedang & 0 & 0 \\
\hline Berat & 0 & 0 \\
\hline \multicolumn{3}{|l|}{ Skor PRAL ${ }^{1}$ (mEq/hari) } \\
\hline$<25,4$ & 22 & 55 \\
\hline$\geq 25,4$ & 18 & 45 \\
\hline \multicolumn{3}{|l|}{ pH urin } \\
\hline$<7,0$ & 38 & 95 \\
\hline$\geq 7,0$ & 2 & 5 \\
\hline \multicolumn{3}{|l|}{ Lingkar pinggang } \\
\hline Obesitas sentral & 29 & 72 \\
\hline Tidak obesitas & 11 & 28 \\
\hline \multicolumn{3}{|l|}{ Kadar trigliserida } \\
\hline Normal & 25 & 62 \\
\hline Tinggi & 15 & 38 \\
\hline \multicolumn{3}{|l|}{ Tekanan darah sistolik } \\
\hline Normal & 14 & 35 \\
\hline Tinggi & 26 & 65 \\
\hline \multicolumn{3}{|l|}{ Tekanan darah diastolik } \\
\hline Normal & 19 & 48 \\
\hline Tinggi & 21 & 52 \\
\hline \multicolumn{3}{|l|}{ Kadar GDP ${ }^{2}$} \\
\hline Normal & 37 & 93 \\
\hline Tinggi & 3 & 7 \\
\hline \multicolumn{3}{|l|}{ Kadar $\mathrm{HDL}^{3}$} \\
\hline Normal & 14 & 35 \\
\hline Rendah & 26 & 65 \\
\hline
\end{tabular}

Protein dan fosfor merupakan zat gizi yang menyumbang keadaan asam dalam tubuh. Diketahui sebanyak 59\% subjek asupan proteinnya lebih dan 5\% subjek memiliki asupan fosfor yang tergolong kurang. Zat gizi kalsium, magnesium, dan kalium merupakan penyumbang basa dalam tubuh. Pada penelitian ini diketahui sebanyak $58 \%$ subjek memiliki asupan magnesium yang kurang, dan semua subjek memiliki asupan kalsium dan kalium yang tergolong kurang.

\section{Keseimbangan asam basa dan kejadian sindrom metabolik}

Tabel 3 menunjukkan hubungan dietary acid load dengan kejadian sindrom metabolik. Diketahui subjek 
yang memiliki skor PRAL lebih dari 25,4 mEq/hari lebih banyak mengalami sindrom metabolik dibandingkan dengan subjek yang memiliki skor PRAL kurang dari 25,4 mEq/hari. Hubungan antara dietary acid load dengan pH urin diuji menggunakan uji korelasi RankSpearman. Berdasarkan hasil pengujian diketahui tidak

Tabel 2. Asupan harian subjek penelitian

\begin{tabular}{lcc}
\hline \multicolumn{1}{c}{ Asupan zat gizi } & n & \% \\
\hline Asupan protein & & \\
Kurang $(<80 \%)$ & 10 & 23 \\
Cukup $(80-100 \%)$ & 6 & 18 \\
Lebih $(>100 \%)$ & 24 & 59 \\
Asupan fosfor & & \\
Cukup $(\geq 1.200 \mathrm{mg})$ & 2 & 5 \\
Kurang $(<1.200 \mathrm{mg})$ & 38 & 95 \\
Asupan kalsium & & \\
Cukup $(\geq 1.200 \mathrm{mg})$ & 0 & 100 \\
Kurang $(<1.200 \mathrm{mg})$ & 40 & \\
Asupan magnesium & & 42 \\
Cukup $(>200 \mathrm{mg})$ & 17 & 58 \\
Kurang $(<200 \mathrm{mg})$ & 23 & 0 \\
Asupan kalium & & 100 \\
Cukup $(>4.700 \mathrm{mg})$ & 0 & \\
Kurang $(<4.700 \mathrm{mg})$ & 40 & \\
\hline
\end{tabular}

Tabel 3. Hubungan dietary acid load dengan sindrom metabolik

\begin{tabular}{lcccccc}
\hline \multirow{2}{*}{ Skor PRAL } & \multicolumn{2}{c}{$\begin{array}{c}\text { Tidak sindrom } \\
\text { metabolik }\end{array}$} & \multicolumn{2}{c}{$\begin{array}{c}\text { Sindrom } \\
\text { metabolik }\end{array}$} & \multirow{2}{*}{$\mathbf{p}$} \\
\cline { 2 - 5 } & $\mathbf{n}$ & $\mathbf{\%}$ & $\mathbf{n}$ & $\mathbf{\%}$ & \\
\hline$>25,4 \mathrm{mEq} /$ hari & 4 & 22 & 14 & 78 & $<0,001^{1}$ \\
$<25,4 \mathrm{mEq} /$ hari & 20 & 91 & 2 & 9 & \\
Total & 24 & 60 & 16 & 40 & \\
\hline
\end{tabular}

${ }^{1}$ Uji Chi-Square ada hubungan antara dietary acid load dengan $\mathrm{pH}$ urin $(\mathrm{r}=-0,236 ; \mathrm{p}=0,999)$.

\section{Dietary acid load, pH urin dan asupan dengan komponen sindrom metabolik}

Tabel 4 menunjukkan hubungan dietary acid load, $\mathrm{pH}$ urin, dan asupan dengan komponen sindrom metabolik. Berdasarkan hasil analisis diketahui bahwa dietary acid load hanya berhubungan dengan lingkar pinggang, tekanan darah sistolik (TDS), tekanan darah diastolik (TDD), dan kadar trigliserida $(\mathrm{p}<0,05)$.

\section{BAHASAN}

Berdasarkan hasil penelitian ini ditemukan prevalensi obesitas pada remaja sebesar 9,1\%. Hasil ini lebih tinggi dibandingkan prevalensi obesitas di Indonesia berdasarkan hasil Riset Kesehatan Dasar (Riskesdas) tahun 2013, yaitu prevalensi obesitas pada remaja berusia 16-18 tahun sebesar 1,6\% (18). Hasil ini juga lebih tinggi dibandingkan dengan penelitian sebelumnya yang dilakukan di sebuah SMA di Kota Semarang, dengan prevalensi obesitas pada remaja sebesar 7,9\% (3). Meningkatnya kejadian obesitas pada remaja menunjukkan bahwa obesitas merupakan masalah yang terus berkembang dan dapat meningkatkan risiko terjadinya sindrom metabolik pada remaja. Pada remaja obesitas juga ditemukan prevalensi sindrom metabolik sebesar $40 \%$, hasil ini lebih tinggi dibandingkan prevalensi sindrom metabolik dalam sebuah penelitian pada remaja obesitas di SMA Negeri di Semarang pada tahun 2014 yakni 15,2\% (3).

Tabel 4. Hubungan dietary acid load, pH urin, dan asupan dengan komponen sindrom metabolik

\begin{tabular}{|c|c|c|c|c|c|c|c|c|c|c|c|c|}
\hline \multirow{2}{*}{ Variabel } & \multicolumn{2}{|c|}{$\mathbf{L P}^{3}$} & \multicolumn{2}{|c|}{ GDP $^{4}$} & \multicolumn{2}{|c|}{ TDS $^{5}$} & \multicolumn{2}{|c|}{ TDD $^{6}$} & \multicolumn{2}{|c|}{$\mathbf{T G}^{7}$} & \multicolumn{2}{|c|}{ HDL $^{8}$} \\
\hline & $\mathbf{r}$ & $\mathbf{p}$ & $\mathbf{r}$ & p & $\mathbf{r}$ & p & $\mathbf{r}$ & p & $\mathbf{r}$ & $\mathbf{p}$ & $\mathbf{r}$ & p \\
\hline PRAL & 0,4 & $0,02^{1}$ & 0,3 & $0,1^{2}$ & 0,6 & $<0,001^{2}$ & 0,7 & $<0,001^{2}$ & 0,4 & $0,02^{2}$ & $-0,2$ & $0,16^{1}$ \\
\hline pH Urin & 0,2 & $0,33^{2}$ & $-0,1$ & $0,9^{2}$ & 0,05 & $0,75^{2}$ & 0,1 & $0,71^{2}$ & $-0,1$ & $0,62^{2}$ & $-0,2$ & $0,24^{2}$ \\
\hline Energi & 0,2 & $0,3^{1}$ & 0,1 & $0,4^{2}$ & 0,2 & $0,4^{2}$ & 0,1 & $0,7^{2}$ & 0,1 & $0,5^{2}$ & 0,004 & $0,9^{1}$ \\
\hline Karbohidrat & 0,3 & $0,1^{1}$ & 0,2 & $0,2^{2}$ & 0,3 & $0,6^{2}$ & 0,2 & $0,1^{2}$ & 0,8 & $0,1^{2}$ & 0,03 & $0,9^{1}$ \\
\hline Protein & 0,2 & $0,2^{1}$ & 0,2 & $0,4^{2}$ & 0,2 & $0,3^{2}$ & 0,1 & $0,4^{2}$ & 0,1 & $0,7^{2}$ & 0,23 & $0,2^{1}$ \\
\hline Lemak & 0,1 & $0,8^{2}$ & 0,1 & $0,9^{2}$ & 0,1 & $0,1^{2}$ & 0,2 & $0,2^{2}$ & 0,4 & $0,1^{2}$ & 0,09 & $0,6^{2}$ \\
\hline
\end{tabular}

${ }^{1}$ Uji korelasi Pearson; ${ }^{2}$ Uji korelasi Rank-Spearman;

${ }^{3} \mathrm{LP}=$ lingkar pinggang; ${ }^{4} \mathrm{GDP}=$ gula darah puasa; ${ }^{5} \mathrm{TDS}=$ tekanan darah sistolik; ${ }^{6} \mathrm{TDD}=$ tekanan darah diastolik; ${ }^{7} \mathrm{TG}=$ trigliserida; ${ }^{8} \mathrm{HDL}=$ high density lipoprotein 
Tingginya prevalensi obesitas dan sindrom metabolik disebabkan oleh beberapa faktor, diantaranya asupan makanan yang berlebih dan kurangnya aktivitas fisik. Asupan makan remaja cenderung berpola Western diet yang tinggi asupan energi, karbohidrat, protein hewani, dan lemak, serta rendah asupan mineral dan serat dari sayur dan buah. Pada penelitian ini diketahui sebanyak 49\% subjek asupan energinya tergolong lebih; $59 \%$ subjek memiliki asupan protein yang tergolong lebih; $63 \%$ subjek memiliki asupan lemak yang tergolong lebih; dan 35\% subjek memiliki asupan karbohidrat yang tergolong lebih. Selain itu, diketahui juga 58\% subjek kekurangan asupan magnesium serta semua subjek kekurangan asupan kalium dan kalsium.

Faktor lain penyebab obesitas adalah kurangnya aktivitas fisik baik kegiatan harian maupun latihan fisik terstruktur. Hal ini sesuai dengan hasil perhitungan aktivitas fisik pada menggunakan kuesioner IPAQ, yaitu semua subjek memiliki skor aktivitas fisik yang tergolong ringan dengan rentang skor 240-594. Hasil penelitian ini sesuai dengan penelitian yang dilakukan di Yogyakarta yang menunjukkan bahwa pada kelompok anak obesitas, lebih banyak yang memiliki aktivitas fisik rendah. Subjek yang memiliki aktivitas fisik tergolong rendah memiliki kecenderungan untuk obes 5,2 kali lebih besar daripada anak yang memiliki aktivitas fisik tinggi (19).

Lebih lanjut, Western diet adalah salah satu diet yang populer di kelompok usia remaja (19). Diet ini kaya akan produk hewani yang dapat menginduksi beban asam tubuh tetapi dengan sedikit asupan sayuran dan buah-buahan (20). Secara umum, makanan yang tinggi prekusor asam sebagian besar berasal dari sumber protein hewani seperti daging, telur, olahan susu, dan juga beberapa bahan makanan serealia sedangkan buah-buahan dan sayuran mengandung prekusor basa (15). Kebiasaan diet seperti ini mampu menyumbakan acid-load pada tubuh kurang lebih $1 \mathrm{mEq} / \mathrm{kg} /$ hari (21). Menurut teori, $\mathrm{pH}$ tubuh ditentukan oleh 3 variabel independen yaitu kadar $\mathrm{pCO} 2$, perbedaan konsentrasi elektrolit kuat yang disebut strong ions difference (SID), dan total konsentrasi asam non-volatil (22). Disebut variabel independen karena variabel-variabel ini diatur dari luar sistem dan secara langsung mempengaruhi sistem keseimbangan asam-basa. Salah satu variabel independen adalah asam non-volatil yang berasal dari asupan protein dan fosfor (22).

Skor PRAL digunakan untuk memperkirakan dietary acid load dalam studi epidemiologi. Skor PRAL memperhitungkan tingkat penyerapan usus terhadap zat gizi yang berkontribusi terhadap keseimbangan asambasa yaitu protein, kalium, kalsium, magnesium, dan fosfor (21). Skor PRAL yang positif mencerminkan asupan yang bersifat lebih asam sedangkan skor PRAL negatif mencerminkan asupan yang bersifat basa. Dalam penelitian ini, seluruh subjek memiliki skor PRAL positif yang menunjukkan bahwa asupan makan responden lebih bersifat asam. Pada penelitian ini diketahui sebanyak 18 subjek (45\%) memiliki skor PRAL lebih dari nilai rerata. Tingginya skor PRAL subjek pada penelitian ini dikarenakan asupan makan subjek yang cenderung tinggi protein serta rendah magnesium, kalium, dan kalsium. Protein merupakan salah satu zat gizi yang menyumbang prekusor asam dalam tubuh sedangkan magnesium, kalium, dan kalsium merupakan zat gizi yang menyumbang prekusor basa dalam tubuh.

Skor PRAL memiliki hubungan yang signifikan terhadap lingkar pinggang $(\mathrm{p}=0,028)$. Hal ini sesuai dengan penelitian sebelumnya di Iran yang mengemukakan bahwa skor PRAL berhubungan dengan lingkar pinggang (20). Rerata lingkar pinggang subjek pada penelitian ini sebesar 92,8 $\pm 0,3 \mathrm{~cm}$ yang menunjukkan kategori obesitas. Skor PRAL juga diketahui berhubungan dengan kadar trigliserida $(\mathrm{p}=0,022)$. Sebuah penelitian yang dilakukan di Korea Selatan mengemukakan hasil yang sama, bahwa tingginya skor PRAL berhubungan dengan tingginya kadar trigliserida (23). Skor PRAL tinggi menunjukkan bahwa asupan gizi bersifat basa seperti magnesium, kalium, dan kalsium yang cenderung kurang dari kebutuhan. Defisiensi magnesium menyebabkan penurunan aktivitas enzim lesitin-kolesterol asiltransferase dan lipoprotein lipase (24). Efek dari penurunan aktivitas enzim tersebut, bersama-sama dengan perubahan ekspresi gen apolipoprotein, menyebabkan katabolisme yang tidak sempurna sebagai faktor utama yang mendasari perubahan dalam profil lipoprotein plasma (24). Hal ini mendukung hipotesis tentang ion mengenai perkembangan penyakit, seperti obesitas dan hipertrigliseridemia. Ion basa sangat berpengaruh terhadap keseimbangan asam-basa. Ion basa 
dapat menjadi jalur yang menghubungkan keseimbangan asam-basa dengan obesitas dan hipertrigliseridemia dan menjelaskan perkembangan penyakit akibat efek jangka panjang dari acidogenic diet.

Skor PRAL juga memiliki hubungan yang signifikan terhadap tekanan darah sistolik $(\mathrm{p}=<0,001)$ dan diastolik $(p=<0,001)$. Penelitian ini sesuai dengan penelitian sebelumnya yang mengemukakan bahwa skor PRAL yang tinggi berhubungan signifikan dengan tekanan darah sistolik dan diastolik pada remaja di Jepang (14). Terkait pengaruh dietary acid load terhadap tekanan darah, beberapa mekanisme telah diusulkan. Asupan rendah kalium dapat mempengaruhi vasodilatasi dan menjadi racun bagi pembuluh darah. Terbatasnya asupan kalium menyebabkan kurangnya kalium di intraseluler dan menyebabkan natrium dalam sel mempertahankan tonisitas dan volume sebagai kompensasi (25). Hasil sebuah penelitian, bahkan periode 10 hari asupan rendah kalium akan menyebabkan peningkatan tekanan darah sistolik sebesar $5 \mathrm{mmHg}(\mathrm{p}<0,02)$ dan sensitivitas garam sehingga dapat menyebabkan hipertensi (26). Mekanisme lain yang mungkin terjadi adalah adanya peningkatan produksi kortisol yang meningkatkan ekskresi kalsium dan mereduksi ekskresi sitrat sehingga menyebabkan peningkatan tekanan darah (27).

Lebih lanjut, penelitian ini juga menemukan bahwa skor PRAL tidak berhubungan dengan kadar GDP. Diketahui kadar GDP sebagian besar subjek $(92,5 \%)$ tergolong normal. Hal ini menunjukkan bahwa hiperglikemia merupakan faktor risiko yang muncul paling akhir di antara faktor risiko sindrom metabolik lainnya pada remaja (28). Kadar GDP normal yang ditemukan pada subjek menunjukkan bahwa metabolisme karbohidrat masih berjalan dengan baik yaitu tubuh dapat mempertahankan kadar glukosa darah normal melalui hormon insulin yang disekresikan pankreas (29).

Hasil penelitian ini menemukan adanya hubungan yang signifikan antara skor PRAL dengan lingkar pinggang, tekanan darah sistolik, tekanan darah diastolik, dan kadar trigliserida. Pada penelitian ini juga diketahui subjek dengan skor PRAL yang lebih dari rerata, terdapat 14 subjek (78\%) yang masuk dalam kriteria sindrom metabolik. Pada penelitian ini, dietary acid load dikaitkan dengan kejadian sindrom metabolik, sejalan dengan penelitian sebelumnya yang melaporkan bahwa skor PRAL berkaitan dengan hipertensi dan diabetes mellitus tipe 2 (20). Berbeda dengan penelitian sebelumnya, hasil penelitian ini menunjukkan tidak adanya hubungan antara pH urin dengan semua komponen sindrom metabolik. Pada penelitian yang dilakukan di Texas pada tahun 2007, diketahui $\mathrm{pH}$ urin berhubungan dengan resistensi insulin dan pada subjek dengan sindrom metabolik diketahui memiliki $\mathrm{pH}$ urin yang cenderung lebih asam dibandingkan dengan orang normal (7). Pada penelitian ini, $\mathrm{pH}$ urin subjek masih tergolong normal dengan nilai $\mathrm{pH} 5,0-7,0 . \mathrm{pH}$ urin subjek yang masih normal ini dikarenakan pada usia remaja, ginjal masih dapat melakukan fungsinya dengan baik untuk mempertahankan keseimbangan asam-basa. Semakin bertambahnya usia, fungsi ginjal akan semakin menurun dan memungkinkan terjadinya kenaikan $\mathrm{H}^{+}$dalam darah dan ekskresi $\mathrm{H}^{+}$ menjadi kurang efisien (9). Teori ini sesuai dengan hasil penelitian yang dilakukan di Kota Semarang pada subjek lansia yang menunjukkan bahwa subjek dengan sindrom metabolik memiliki pH urin yang lebih asam (30).

\section{SIMPULAN DAN SARAN}

Penelitian ini menemukan adanya hubungan yang signifikan antara skor PRAL dengan lingkar pinggang, TDS, TDD, dan kadar trigliserida. Tingginya dietary acid load dapat menjadi salah satu faktor risiko terjadinya sindrom metabolik pada remaja obesitas. Diperlukan pemberian edukasi kepada remaja obesitas berupa pentingnya mengatur pola makan. Pola makan remaja yang cenderung tinggi protein hewani sebaiknya dikurangi dan diimbangi dengan konsumsi protein nabati karena protein nabati hanya memiliki sedikit pengaruh dalam pemberian beban asam dalam tubuh. Selain itu, pola makan remaja juga sebaiknya diimbangi dengan asupan tinggi kalium, magnesium, dan kalsium yang memberikan sifat basa pada tubuh, yang dapat ditemukan pada bahan makanan sayuran dan buah-buahan. Peningkatan konsumsi sayur dan buah bisa dimulai dengan mengkonsumsi jus buah atau buah potong yang mudah dijumpai di kantin sekolah. Pemberian edukasi mengenai pentingnya aktivitas fisik pada remaja obesitas juga diperlukan. 


\section{Pernyataan konflik kepentingan}

Penulis menyatakan tidak ada konflik kepentingan dengan pihak-pihak yang terkait dalam penelitian ini.

\section{RUJUKAN}

1. Arisman. Obesitas, diabetes mellitus, dan dislipidemia. Jakarta: Buku Kedokteran; 2008.

2. The Asia-Pasific perspective: redefining obesity and its treatment. Australia: Health Communications Australia; 2000.

3. Rachmawati S, Sulchan M. Asupan lemak dan kadar high density lipoprotein (HDL) sebagai faktor risiko peningkatan kadar C-reactive protein (CRP) pada remaja obesitas dengan sindrom metabolik. Journal of Nutrition College 2014;3(3):337-45.

4. Locatelli F, Pozzoni P, Del Vecchio L. Renal manifestations in the metabolic syndrome. JAm Soc Nephrol 2006;17(Suppl 7):S81-5.

5. Zhang R, Liao J, Morse S, Donelon S, Reisin E. Kidney disease and the metabolic syndrome. Am J Med Sci 2005;330:319-25.

6. Chagnac A, Weinstein T, Korzets A, Ramadan E, Hirsch J, Gafter U. Glomerular hemodynamics in severe obesity. Am J Physiol Renal Physiol 2000;278:F817-22.

7. Maalouf NM, Cameron MA, Moe OW. Low urine pH: a novel feature of the metabolic syndrome. Clin J Am Soc Nephrol 2007;883-8.

8. Corwin EJ. Patofisiologi. Nike Budhi (Alih bahasa). Jakarta: EGC; 2009.

9. Welch AA, Mulligan A, Bingham SA, Khaw KT. Urine pH is an indicator of dietary acid-base load, fruit and vegetables and meat intakes: results from the European Prospective Investigation into Cancer and Nutrition (EPIC)-Norfolk population study. Br J Nutr 2008;99(6):1335-43.

10. Remer T, Dimitriou T, Manz F. Dietary potential renal acid load and renal net acid excretion in healthy, free-living children and adolescents. Am J Clin Nutr 2003;77(5):1255-60.

11. Remer T, Manz F. Potential renal acid load of foods and its influence on urine pH. J Am Diet Assoc 1995;95:791-7.

12. Engberink MF, Bakker SJ, Brink EJ, van Baak MA, van Rooij FJ, Geleijnse JM, et al. Dietary acid load and risk o f hypertension: the Rotterdam Study. Am J Clin Nutr 2012;95(6):1438-44.

13. Welch AA. Dipstick measurement of urinary ph have potential for monitoring individual and population dietary behaviors. The Open Nutrition Journal 2008;2:63-6.

14. Murakami K, Sasaki S, Takahashi Y, Uenishi K. Association between dietary acid-base load and cardiometabolic risk factors in young Japanese women. Br J Nutr 2008;100(3):642-51.

15. Fahregazzi G, Alice V, Fabrice B, Martin L, Beverley B. Dietary acid load and risk of type 2 diabetes: the E3N-EPIC cohort study. Diabetologia 2014;57(2):313-20.

16. Adult Treatment Panel III (ATP III). Executive summary of the third report of the national cholesterol education program education program (NCEP) expert panel on detection, evaluation and treatment of high blood cholesterol in adult (Adult treatment panel III). JAMA 2001;285(19):2476-97.

17. Falkner B, Daniels SR, Flynn JT, Gidding S, Green LA, Inelfinger JR, et al. The fourth report of the diagnosis evaluation and treatment of high blood pressure children and adolescents. Pediatrics 2004;114(2 Suppl 4th Report):555-76.

18. Badan Penelitian dan Pengembangan Kesehatan Kementerian RI tahun 2013. Riset kesehatan dasar (Riskesdas). [series online] 2013 [cited 20 September 2016]. Available from: URL: http://www.depkes.go.id/ resources/download/general/Hasil\%20Riskesdas\%20 2013.pdf.

19. Pampang E, Purba MB, Huriyati E. Asupan energi, aktivitas fisik, persepsi orang tua, dan obesitas siswa dan siswi SMP di Kota Yogyakarta. Jurnal Gizi Klinik Indonesia 2009;5(3):108-13.

20. Bahadoran Z, Mirmiran P, khosravi H, Azizi F. Association between dietary acid-base load and cardiometabolic risk factors in adults: The Tehran Lipid and Glucose Study. Endocrinol Metab 2015;30:201-7.

21. Remer T, Dimitriou T, Manz F. Dietary potential renal acid load and renal net acid excretion in healthy, free-living children and adolescents. Am J Clin Nutr 2003;77(5):1255-60.

22. Stewart PA. Stewart's textbook of acid-base. USA: Paul WG Elbers; 2009.

23. Han E, Kim G, Hong N, Lee Y, Kim DW, Cha BS, et al. Association between dietary acid load and the risk of cardiovascular disease: nationwide surveys (KNHNES 2008-2011). Cardiovasc Diabetol 2016;15(1):122.

24. Berkemeyer S. Acid-base balance and weight gain: are there crucial links via protein and organic acids in understanding obesity? Med Hypotheses 2009;73(3):347-56.

25. Maurer M, Riesen W, Muser J, Hulter HN, Krapf R. Neutralization of Western diet inhibits bone resorption independently of $\mathrm{K}$ intake and reduces cortisol secretion in humans. Am J Physiol Renal Physiol 2003;284(1):F3240.

26. Kotchen TA, Kotchen JM. Nutrition, diet, and hypertension. In: Shils ME, Shike M, Ross AC, Caballero B, Cousins $\mathrm{RJ}$, editors. Modern nutrition in health and disease. 10th 
Edition. Philadelpia: Lippincott Williams and Wilkins; 2006.

27. Taylor EN, Mount DB, Forman JP, Curhan GC. Association of prevalent hypertension with 24-hour urinary excretion of calcium, citrate, and other factors. Am J Kidney Dis 2006;47:780-9.

28. Rizzo ACB, Goldberg TBL, Silva CC, Kurokawa CS, Nunes HR, Corrente JE. Metabolic syndrome risk factors in overweight, obese, and extremely obese Brazilian adolescents. Nutr J 2013;12:19.

29. Buse JB, Kenneth SP, Charles FB. Type 2 diabetes mellitus. William Textbook of Endocrinology 2002;1427-51.

30. Widyastuti N, Sulchan M, Johan A. Asupan makan, sindrom metabolik, dan status keseimbangan asambasa tubuh pada lansia. Jurnal Gizi Klinik Indonesia 2013;9(4):179-87. 